\title{
TERAPI TADABBUR AL-QUR'AN UNTUK MENGURANGI KECEMASAN MENGHADAPI PERSALINAN PERTAMA
}

\section{AL-QUR'AN TADABBUR THERAPY TO REDUCE ANXIETY ON THE FIRST DELIVERY}

\author{
Dini A.P. Prapto \\ H. Fuad Nashori \\ Rumiani \\ Fakultas Psikologi dan Ilmu Sosial Budaya Universitas Islam Indonesia Yogyakarta \\ Emai: afifah_padma@yahoo.com
}

\begin{abstract}
During pregnancy, women experience significant changes in physiological and psychological functions. The research data shows that the process of pregnancy becomes a source of anxiety. This study aimed to examine the effect of Al-Qur'an Tadabbur therapy to reduce anxiety on the first delivery. Subjects are two groups of pregnant women. Measuring instruments used in this study is the Maternal Anxiety Scale were given before and after treatment and during follow-up. The first group received Al-Qur'an Tadabbur therapy, while the second group was the control group (waiting list). The difference (gain score) of pre-test, post-test and follow-up were compared by using Mann-Whitney analysis to determine whether there are significant differences in anxiety gain score. The result is the group who followed the Al-Qur'an Tadabbur therapy has lower anxiety score, $p=0.032(p<0.05)$ compared with the control group. This study shows that Al Quran Tadabbur therapy can be used as one of the way to reduce anxiety before delivery.
\end{abstract}

Key Words : Anxiety, Al-Qur'an Tadabbur Therapy, Pregnancy

\begin{abstract}
ABSTRAK
Saat kehamilan, ibu mengalami perubahan yang signifikan pada fungsi fisiologis dan psikologisnya. Data penelitian menunjukkan bahwa proses kehamilan menjadi salah satu sumber kecemasan. Penelitian ini bertujuan untuk menguji pengaruh Terapi Tadabbur Al-Qur'an untuk mengurangi kecemasan menghadapi persalinan pertama. Subjek adalah 2 kelompok ibu hamil. Alat ukur yang digunakan dalam penelitian ini adalah Skala Kecemasan Ibu Hamil yang diberikan pada saat sebelum dan setelah terapi serta pada saat tindak lanjut. Kelompok pertama mendapatkan Terapi Tadabbur Al-quran, sedangkan kelompok kedua dijadikan sebagai kelompok kontrol. Selisish (gain score) prates, pascates dan tindak lanjut kemudian dibandingkan dengan menggunakan analisis Mann-Whitney untuk mengetahui apakah terdapat perbedaan gain score kecemasan yang signifikan. Hasilnya adalah kelompok subjek yang mengikuti Terapi Tadabbur Al-Qur'an mengalami penurunan kecemasan $p=0,032(p<0,05)$ dibandingkan dengan kelompok kontrol. Penelitian ini menunjukkan bahwa Terapi Tadabbur Al-Qur'an dapat digunakan sebagai salah satu cara untuk menurunkan kecemasan menjelang persalinan.
\end{abstract}

Kata kunci : Kecemasan, Terapi Tadabbur Al-quran, Kehamilan 
Kehamilan merupakan hal yang paling ditunggu sekaligus mendatangkan rasa gelisah bagi pasangan suami dan istri. Setiap wanita akan mengharapkan kehamilan yang berjalan dengan lancar, sehat secara fisik, serta mengalami proses persalinan yang berjalan dengan lancar pula. Harapan ini membuat ibu hamil menikmati proses kehamilannya. Namun, rasa gelisah dan cemas hampir selalu menyertai kehamilan. Bagian ini merupakan suatu proses penyesuaian yang wajar terhadap perubahan fisik dan psikologis yang terjadi selama kehamilan. Perubahan ini terjadi akibat perubahan hormon yang akan mempermudah janin untuk tumbuh dan berkembang sampai saat dilahirkan (Kushartanti, Soekamti \& Sriwahayuniati, 2004).

Kecemasan, menurut McNerney dan Greenberg (Nolan, 2003), merupakan suatu reaksi fisik, mental, kimiawi dari tubuh terhadap situasi yang menakutkan, mengejutkan, membingungkan, membahayakan, dan merisaukan seseorang. Reaksi ini terjadi pada begitu banyak individu. Menurut Bergner (2011), prevalensi gangguan kecemasan mencapai $21 \%-43 \%$.

Penelitian Mandasari (2010) yang dilakukan pada 36 orang ibu hamil dengan usia 26-30 tahun menunjukkan sebanyak 15 orang atau 41,7\% mengala- mi kecemasan dalam menghadapi persalinan. Berdasarkan tingkat kecemasan diketahui hampir seluruh ibu hamil mengalami kecemasan berat saat menjelang persalinan, baik pada primigravida (ibu yang sedang hamil untuk pertama kali) maupun multigravida (ibu yang hamil lebih dari satu sampai lima kali), yaitu sebanyak 24 orang atau $66,7 \%$. Zamriati, Hutagaol, dan Wowling (2013) menyatakan bahwa dari 158 responden yang diteliti pada kategori graviditas diperoleh kecemasan yang dialami oleh primigravida $66,2 \%$ lebih tinggi dibandingkan multigravida 42,2\%.

Susmayanti (2014) mengatakan bahwa Angka Kematian Ibu (AKI) di DIY cukup tinggi. Hingga Mei 2014, jumlahnya sudah mencapai 250 orang dan sebagian besar masih berusia produktif antara 30-40 tahun. Tingginya AKI di DIY dipicu kondisi ibu hamil yang stres sehingga berpengaruh terhadap kesehatannya. Menurut data DINKES kota Yogyakarta (2010), Angka Kematian Ibu (AKI) pada tahun 2008 sebanyak 104/100.000. Untuk jumlah kematian internal yang dilaporkan kabupaten/kota Sleman pada tahun 2010 mencapai 43 kasus dan pada tahun 2009 sebanyak 48 kasus. Salah satu penyebab persalinan yang lama sehingga menimbulkan 
kematian adalah gangguan psikologis, seperti perasaan cemas dan takut.

Menurut Blackburn (Fidianty \& Noviastuti, 2010), bila kecemasan ini berlebihan dan tidak sebanding dengan situasi, maka akan berubah menjadi masalah klinis. Kecemasan yang dirasakan wanita hamil akan berdampak pada janin yang dikandungnya. Menurut Stanley dan Oberta (Lestariningsih, 2005), ibu hamil yang seringkali merasa khawatir bahkan stres memiliki kecenderungan untuk melahirkan bayi prematur. Hal ini terjadi karena stres dan kecemasan memicu produksi Corticotropin Releasing Hormone $(\mathrm{CRH})$. Hormon ini juga memiliki fungsi sebagai "tanda" bila persalinan akan tiba.

\section{Psikologi kontemporer menawar-} kan berbagai cara untuk menurunkan kecemasan ibu hamil menjelang persalinan. Hal ini dapat diketahui dari penelitian Sukandar (2009) tentang "keefektifan Cognitive Behavior Therapy (CBT) untuk menurunkan tingkat kecemasan pada ibu hamil di Rumah Sakit PKU Muhammadiyah Surakarta", Annatagia (2010) tentang "relaksasi bumil sehat untuk menurunkan kecemasan ibu hamil resiko tinggi", Rahmawati (2010) tentang "perbedaan tingkat kecemasan ibu primigravida trimester III sebelum dan sesudah pemberian musik klasik", Suprijati (2011) tentang "efektivitas pemberian aromaterapi untuk menurunkan kecemasan ibu hamil trimester III dalam persiapan menghadapi persalinan", Kusumajati (2012) tentang "hypnobirthing therapy untuk mengurangi kecemasan menghadapi persalinan pertama" dan Resmaniasih (2014) tentang "pengaruh teknik pernafasan diagfragma terhadap kecemasan pada ibu hamil trimester III".

Intervensi yang diberikan pada penelitian sebelumnya memiliki kelebihan mampu menurunkan tingkat kecemasan pada ibu hamil. Di sisi lain peneliti bermaksud menggunakan salah satu bentuk psikoterapi Islam sebagai bentuk perkembangan dari psikologi Islam. Psikoterapi Islam searah dengan hadist $\mathrm{Nabi}$ Muhammad SAW sebagaimana yang diriwayatkan oleh Muslim dan Ahmad (dari Jabbir bin Abdullah r.a) bersabda: "Setiap penyakit ada obatnya. Jika obat itu tepat mengenai sasarannya maka dengan izin Allah penyakit itu akan sembuh" (Hawari, 1997). Selain itu, psikoterapi Islam membuat keyakinan yang dimiliki bertahan lebih lama, sehingga memiliki efek lebih lama. Menurut Maimunah dan Retnowati (2011), sarana yang terbukti efektif untuk mengurangi kecemasan menjelang persalinan adalah dengan religious coping. 
Salah satu di antara religious coping adalah dengan tadabbur Al-Qur'an. Menurut Qadri (2003), Al-Qur'an sebagai petunjuk dan jalan keluar bagi segala macam persoalan. Segala sumber penyakit, bisa diobati dengan Al-Qur'an. Diriwayatkan Ibnu Majjah dari Ali Ra, "Sebaik-baik obat ialah Al-Qur'an". Menurut Najati (2004), Al-Qur'an merupakan pedoman yang mampu mengobati segala macam penyakit termasuk gangguan kecemasan, sehingga hati akan menjadi tenang, pikiran terkendali, dan jiwa terasa lapang.

Berdasarkan penjelasan di atas, diajukan hipotesis dalam penelitian ini bahwa ibu hamil yang mendapatkan Terapi Tadabbur Al-Qur'an akan mengalami penurunan kecemasan dalam menghadapi persalinan anak pertama. Sebaliknya yang tidak mendapatkan Terapi Tadabbur Al-Qur'an tidak mengalami penurunan kecemasan.

\section{METODE PENELITIAN}

\section{Rancangan Eksperimen}

Rancangan penelitian yang digunakan adalah pretest-posttest control group design, yakni sebagai berikut:

Tabel 1. Rancangan KE dan KK

\begin{tabular}{ccccc}
\hline Kelompok & Prates & Perlakuan & Pascates & Tindak Lanjut \\
\hline KE & O1 & $\mathrm{X}$ & $\mathrm{O} 2$ & $\mathrm{O} 3$ \\
KK & $\mathrm{O} 1$ & $-\mathrm{X}$ & $\mathrm{O} 2$ & $\mathrm{O} 3$ \\
\hline
\end{tabular}

Keterangan :

KE : Kelompok Eksperimen

KK : Kelompok Kontrol

O1 : Pemberian prates dengan menggunakan skala kecemasan ibu hamil

$\mathrm{O} 2$ : Pemberian pascates dengan menggunakan skala kecemasan ibu hamil

O3 : Pemberian tindak lanjut setelah terapi selesai dilaksanakan

$\mathrm{X}$ : Proses terapi membaca dan men-tadabburi Al-Quran

-X : Tidak ada proses terapi membaca dan men-tadabburi Al-Quran

Pelaksanaan terapi kelompok kon- surat cinta dari-Nya" yang dilakukan trol (waiting list) akan mendapatkan sesi "perjalanan kehamilan" dan psikoedusetelah terapi kelompok eksperimen selesai dilaksanakan.

kasi berupa pemberian materi "Al-Quran 


\section{Subjek Penelitian}

Karakteristik subjek penelitian yang digunakan dalam penilitian ini adalah (a) Ibu hamil anak pertama yang berusia 2035 tahun, (b) Usia kandungan memasuki trimester kedua (14 minggu), (c) Beragama Islam, (d) Mampu membaca AlQuran, (e) Mengalami kecemasan sedang maupun tinggi dalam menghadapi persalinan

\section{Metode Pengambilan Data}

Skala yang digunakan dalam penelitian ini adalah skala kecemasan untuk mengukur kecemasan ibu hamil anak pertama menjelang persalinan yang disusun oleh Sijangga (2010). Skala kecemasan ini terdiri dari 30 aitem pertanyaan (15 aitem favourable dan 15 aitem unfavourable). Penelitian ini meng- gunakan skala yang sudah di try out oleh Prapto (2013). Jumlah subjek yang digunakan 30 orang ibu hamil anak pertama yang memiliki koefisien korelasi aitem total yang bergerak antara 0,366 hingga 0,764 dengan koefisien alpha yang menunjukkan angka 0,906.

\section{Prosedur Intervensi}

Terapi tadabbur Al-Qur'an dirancang untuk dilaksanakan selama 3 kali pertemuan, setiap pertemuan dilakukan selama kurang lebih 60-100 menit dengan dipandu oleh seorang terapis.

Terapi pun siap dilakukan setelah melalui profesional judgement modul. Kelompok pertama yang diberikan terapi adalah kelompok eksperimen, sedangkan kelompok kontrol masuk dalam waiting list.

Tabel 2. Kegiatan terapi membaca dan men-tadabburi Al-Quran

\begin{tabular}{|c|c|c|c|}
\hline Pertemuan & Waktu & Kegiatan & Tujuan \\
\hline I & $5^{\prime}$ & Pembukaan & Membuka sesi terapi \\
\hline \multirow[t]{3}{*}{$100^{\prime}$} & $5^{\prime}$ & Perkenalan & $\begin{array}{ll}\text { - } & \text { Saling mengenal antara partisipan dan tim fasilitator } \\
\text { - } & \text { Menumbuhkan suasana akrab dalam kelompok }\end{array}$ \\
\hline & $5^{\prime}$ & $\begin{array}{l}\text { Penjelasan } \\
\text { maksud dan } \\
\text { tujuan terapi }\end{array}$ & $\begin{array}{l}\text { - Partisipan mengerti mengenai maksud, tujuan dan } \\
\text { manfaat terapi } \\
\text { - Penjelasan mengenai norma kelompok } \\
\text { - Pengisian informed consent }\end{array}$ \\
\hline & $30^{\prime}$ & $\begin{array}{l}\text { "Perjalanan } \\
\text { Kehamilan" }\end{array}$ & 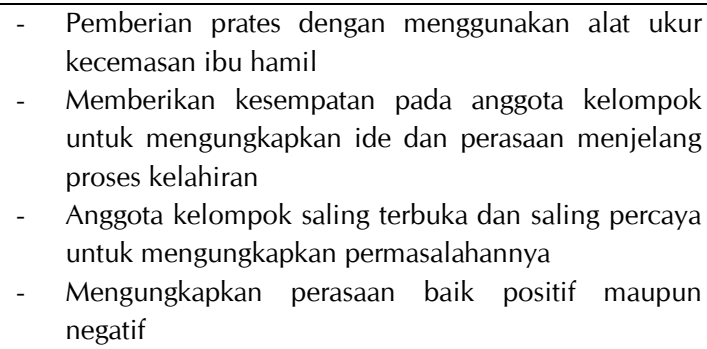 \\
\hline
\end{tabular}




\begin{tabular}{|c|c|c|c|}
\hline Pertemuan & Waktu & Kegiatan & Tujuan \\
\hline & & & $\begin{array}{l}\text { - } \quad \text { Belajar mendengarkan, saling memberi dukungan } \\
\text { antar anggota kelompok }\end{array}$ \\
\hline & $20^{\prime}$ & $\begin{array}{l}\text { "Al-quran, surat } \\
\text { cinta dari-Nya" }\end{array}$ & $\begin{array}{l}\text { - } \text { Partisipan mengetahui pentingnya mentadabburi Al- } \\
\text { quran } \\
\text { - Partisipan mengetahui manfaat mentadabburi Al- } \\
\text { quran secara psikologis }\end{array}$ \\
\hline & $30^{\prime}$ & $\begin{array}{l}\text { "Latihan" } \\
\text { mentadabburi Al- } \\
\text { quran } 1 \text {, dan } \\
\text { pemberian tugas } \\
\text { rumah }\end{array}$ & $\begin{array}{l}\text { - } \text { Partisipan berlatih untuk membaca kemudian } \\
\text { mentadaburri makna dari ayat yang telah dibaca } \\
\text { - } \text { Partisipan berlatih di rumah untuk meningkatkan } \\
\text { keterampilan dalam membaca dan mentadabburi Al- } \\
\text { quran }\end{array}$ \\
\hline & $5^{\prime}$ & $\begin{array}{l}\text { Menutup } \\
\text { pertemuan } \\
\text { pertama }\end{array}$ & $\begin{array}{l}\text { Mengingatkan partisipan } \\
\text { pertemuan berikutnya }\end{array}$ \\
\hline \multirow[t]{5}{*}{$\begin{array}{c}\mathrm{II} \\
100^{\prime}\end{array}$} & $30^{\prime}$ & $\begin{array}{l}\text { Sharing tugas } \\
\text { rumah dan } \\
\text { review } \\
\text { pertemuan } \\
\text { sebelumnya }\end{array}$ & $\begin{array}{l}\text { Mengetahui sejauh mana partisipan memahami materi } \\
\text { yang telah diberikan pada pertemuan sebelumnya }\end{array}$ \\
\hline & $45^{\prime}$ & $\begin{array}{l}\text { "Berbagi } \\
\text { Pengalaman" }\end{array}$ & $\begin{array}{l}\text { Menceritakan pengalaman pemateri selama } \text { proses } \\
\text { kehamilan sebagai bekal bagi para peserta } \\
\text { menghadapi proses kelahiran }\end{array}$ \\
\hline & $15^{\prime}$ & $\begin{array}{l}\text { Latihan } \\
\text { metadabburi Al- } \\
\text { quran } 2\end{array}$ & $\begin{array}{l}\text { Partisipan berlatih untuk meningkatkan keterampilan } \\
\text { mentadabburi Al-quran }\end{array}$ \\
\hline & $5^{\prime}$ & $\begin{array}{l}\text { Pemberian tugas } \\
\text { rumah }\end{array}$ & $\begin{array}{l}\text { Partisipan berlatih di rumah untuk meningkatkan } \\
\text { keterampilan mentadabburi Al-quran }\end{array}$ \\
\hline & $5^{\prime}$ & $\begin{array}{l}\text { Menutup } \\
\text { pertemuan kedua }\end{array}$ & $\begin{array}{l}\text { Mengingatkan partisipan } \\
\text { pertemuan berikutnya }\end{array}$ \\
\hline \multirow[t]{3}{*}{$\begin{array}{l}\text { III } \\
65^{\prime}\end{array}$} & $40^{\prime}$ & $\begin{array}{l}\text { Mengungkapkan } \\
\text { agenda yang } \\
\text { telah tercapai }\end{array}$ & $\begin{array}{l}\text { Partisipan mendapatkan manfaat dari terapi mentadaburi } \\
\text { Al-quran }\end{array}$ \\
\hline & $15^{\prime}$ & $\begin{array}{l}\text { Evaluasi } \\
\text { keseluruhan } \\
\text { terapi }\end{array}$ & $\begin{array}{ll}\text { - } & \text { Mengevaluasi keseluruhan terapi } \\
\text { - } & \text { Melakukan pascates }\end{array}$ \\
\hline & $10^{\prime}$ & Terminasi & Mengakhiri keseluruhan terapi \\
\hline
\end{tabular}

Teknik Analisis Data

HASIL PENELITIAN

Analisis data yang digunakan

dalam penelitian ini adalah statistik non-

Hasil Uji Asumsi

parametrik yaitu Mann-Whitney diguna-

Uji asumsi dilakukan dengan

kan untuk melihat perbedaan antara menggunakan uji normalitas dan uji

kelompok eksperimen dan kelompok homogenitas. Uji normalitas dilakukan kontrol (Levin, 2005). dengan bantuan program SPSS 20 for 
windows dengan menggunakan one uji asumsi menunjukkan bahwa data sample kolmogorov-smirnov test. Hasil tidak normal.

Tabel 3. Hasil Uji Normalitas

\begin{tabular}{cccc}
\hline Perlakuan & Statistik & P & Keterangan \\
\hline $\begin{array}{c}\text { Prates Eksperimen } \\
\text { - Prates Kontrol }\end{array}$ & 0,305 & 0,048 & $\begin{array}{c}\text { Tidak } \\
\text { Normal }\end{array}$
\end{tabular}

Uji homogenitas dilakukan dengan Hasil uji asumsi homogenitas menunjukbantuan program SPSS 20 for windows. kan bahwa data tidak homogen.

Tabel 4. Uji Homogenitas

\begin{tabular}{cccc}
\hline Perlakuan & Levene Statistic & $\mathrm{P}$ & Keterangan \\
\hline $\begin{array}{c}\text { Prates } \\
\text { Eksperimen - } \\
\text { Prates Kontrol }\end{array}$ & 9,993 & 0,025 & $\begin{array}{c}\text { Tidak } \\
\text { Homogen }\end{array}$ \\
\hline
\end{tabular}

\section{Hasil Uji Hipotesis}

Berdasarkan uji asumsi, syarat untuk melakukan uji hipotesis secara parametrik tidak terpenuhi. Oleh karena itu, uji hipotesis harus dilakukan dengan metode nonparametrik, yaitu dengan menggunakan analisis uji beda MannWhitney dengan bantuan program SPSS 20 for windows.

Tabel 5. Uji Beda dengan Menggunakan Skor Skala Kecemasan

\begin{tabular}{ccc}
\hline & $\mathrm{Z}$ & $\mathrm{P}$ \\
\hline Prates & $-0,892$ & 0,372 \\
Pascates & $-1,249$ & 0,212 \\
Tindak Lanjut & $-2,141$ & 0,032 \\
\hline
\end{tabular}

Skor prates menunjukkan tidak ada perbedaan kecemasan antara kelompok eksperimen dan kelompok kontrol dengan signifikansi $p=0,372(p>0,05)$. Tabel tersebut juga menunjukkan bahwa tidak ada perbedaan kecemasan antara kelompok eksperimen dan kelompok kontrol pada saat pascates dengan nilai signifikasi $p=0,212(p>0,05)$. Selanjutnya tabel tersebut menunjukkan bahwa 
ada perbedaan kecemasan antara kelompok eksperimen dan kelompok kontrol pada saat tindak lanjut. Skor dikatakan ada perbedaan jika nilai $p<0,05$. Nilai signifikansinya $p=0,032(p<0,05)$.

\section{Analisis Masing-Masing Kelompok}

Pada kelompok eksperimen terjadi perubahan rerata skor tingkat kecemasan, yaitu dari 74,25 pada saat prates menjadi 63,75 pada saat pascates. Pada kelompok kontrol terjadi perubahan skor kecemasan, yaitu dari 68 pada saat prates meningkat menjadi 70,67 pada saat pascates. Skor prates, pascates dan tindak lanjut dikelompok eksperimen mengalami penurunan hingga masa tindak lanjut pada dua subjek (satu subjek berada kategori rendah, satu subjek berada kategori sedang). Satu subjek mengalami skor yang sama pada saat pascates dan tindak lanjut (masuk kategori rendah), sedangkan satu subjek lagi mengalami kenaikan skor dari pascates ke tindak lanjut (masih masuk dalam kategori rendah). Walau demikian, rerata skor kecemasan pada kelompok eksperimen bergerak turun dari 63,75 (pascates) menjadi 60,75 (tindak lanjut). Skor ini menunjukkan bahwa efek terapi masih ada dalam kurun waktu dua minggu setelah terapi selesai. Skor prates, pascates dan tindak lanjut pada kelompok kontrol mengalami peningkatan dari 70,67 (pascates) menjadi 71,67 (tindak lanjut). Skor ini menunjukkan bahwa pada kelompok kontrol mengalami kecemasan yang bertambah.

\section{PEMBAHASAN}

Penelitian ini bertujuan untuk mengetahui perubahan kecemasan pada ibu hamil yang diberikan terapi Tadabbur Al-Qur'an. Berdasarkan hasil penelitian dan analisis data yang telah dilakukan, peneliti menemukan bahwa tidak ada perbedaan tingkat skor kecemasan antara kelompok eksperimen yang diberikan terapi dengan tadabbur Al-Qur'an dengan kelompok kontrol yang tidak diberikan terapi. Akan tetapi, hasil penelitian ini menunjukkan bahwa skor angka kecemasan mengalami penurunan walau masih dalam kategori yang sama, yakni sedang. Selain itu, penelitian ini juga menunjukkan bawa ada perbedaan tingat kecemasan pada kelompok eksperimen dan kelompok kontrol pada saat tindak lanjut. Hal ini juga diperkuat dari data kualitatif yang menyatakan bahwa ada perbedaan skor kecemasan antara kelompok eksperimen dan kelompok kontrol pada saat pascates dan tindak lanjut. Sementara skor kecemasan pada kelompok kontrol yang tidak 
mendapatkan Terapi Tadabbur Al-Qur'an mengalami kenaikan skor angka Hal ini menunjukkan bahwa terapi Tadabbur AlQur'an sebagai intevensi mampu untuk menurunkan kecemasan pada ibu hamil.

Penelitian ini mendukung teori Najati (2004) dan Hawari (1997) serta hasil riset yang dilakukan oleh Mulyadi, Hidayah dan Mahfur (2012) yang menyatakan bahwa Al-Qur'an dapat menyembuhkan berbagai penyakit jasmani maupun rohani, seperti kegelisahan, kecemasan dan kejiwaan. Hasil penelitian ini semakin menguatkan penelitian sebelumnya yang telah membuktikan bahwa terapi berbasis agama dapat meningkatkan kesehatan jiwa seseorang (Qadri, 2003; Nashori, 2005; Kuchan, 2007; Breslin \& Lewis, 2008; Mardiyono \& Songwathana, 2009; Trimulyaningsih, 2009; Shaleh, 2010; Purwoko, 2013). Hasil penelitian Maimunah \& Retnowati (2011); Mulyadi, Hidayah \& Mahfur (2012) ini secara khusus mendalami bahwa psikoterapi islami mampu untuk menurunkan kecemasan. Penelitian ini juga menunjukkan bahwa Terapi Tadabbur Al-Qur'an terbukti dapat meningkatkan kesehatan jiwa dengan cara mengurangi rasa cemasnya khusus bagi ibu hamil menjelang proses persalinannya. Penelitian ini menambah fakta bahwa terapi yang berbasis agama (terutama islami) juga dapat menurunkan kecemasan dan meningkatkan kesehatan jiwa.

Tadabbur Al-Qur'an sebagai salah satu cara untuk membuat manusia lebih mensyukuri karunia dan rahmat dari Allah SWT, sehingga manusia lebih merasakan ketenangan dan kebahagiaan. Al-Qur'an diartikan sebagai bacaan dan merupakan petunjuk bagi orang yang beriman. Barang siapa yang membaca AlQur'an akan dibalas oleh Allah sebagai suatu kebaikan (Elzaky, 2011; Qadri, 2003). Al-Qur'an sejatinya merupakan obat yang menyembuhkan dan menyehatkan manusia (Hawari, 1997). Sebagai umat muslim, kita harus mempercayai bahwa Al-Qur'an merupakan pedoman yang mampu mengobati segala macam penyalit, termasuk gangguan kecemasan. Membaca dan mentadabburi al-Qur'an dengan tenang dan menghayati akan berdampak pada penurunan rasa cemas, hati menjadi lebih tenang, pikiran terkendali dan jiwa terasa lebih lapang (Najati, 2004).

\section{SIMPULAN DAN SARAN}

\section{Simpulan}

Hasil penelitian ini menunjukkan bahwa Terapi Tadabbur Al-Qur'an dapat mengurangi tingkat kecemasan pada ibu hamil. Kelompok yang mendapatkan 
intervensi Terapi Tadabbur Al-Qur'an lebih rendah kecemasannya dibandingkan dengan kelompok yang tidak mendapatkan Terapi Tadabbur AlQur'an.

\section{Saran}

Ada dua buah saran. Pertama: saran untuk peneliti berikutnya. Terapi Tadabbur Al-Qur'an terbukti mampu menurunkan kecemasan pada ibu hamil menjelang persalinan. Hasil ini bisa menjadi acuan bagi peneliti berikutnya untuk mengembangkan Terapi Tadabbur dengan menggunakan ayat-ayat AlQur'an yang lain. Peneliti bisa menambah Terapi Kelompok sebagai bagian dari Terapi Tadabbur AI-Qur'an untuk melihat hubungan terapeutik tehadap kelompoknya. Akhirnya memunculkan faktor dukungan antara sesama anggota kelompok, faktor ketebukaan diri sesama anggota kelompok serta faktor-faktor lainnya yang bisa terungkap melalui Terapi Kelompok. Selain itu, perlu ada pengecekan manipulasi guna mengantisipasi bahwa intervensi sudah sesuai dengan tujuan penelitian.

Kedua: Saran untuk subjek penelitian. Subjek penelitian diharapkan untuk dapat menerapkan pengetahuan, informasi, ide maupun saran yang telah didapatkan pada saat proses terapi.
Adalah hal yang baik juga ketika subjek mampu untuk berbagi apa yang telah ia dapatkan kepada orang lain (terutama ibu hamil lainnya).

\section{DAFTAR PUSTAKA}

Annatagia, L. (2010). Relaksasi Bumil Sehat untuk Menurunkan Kecemasan Ibu Hamil Resiko Tinggi. Tesis. (Tidak Diterbitkan). Universitas Gadjah Mada.

Bergner. D.W. (2011). Effect of Informed Consent Format on Patient Anxiety Knowledge, and Satisfaction. American Heart Journal. 162(4), 780-785

Breslin, M. J \& Lewis, C. A. (2008). Theoritical models of the nature of prayerand health: a review. Journal of mental health, Religion and Culture. 11(1), 9-21

Dinkes Kota Yogyakarta. (2010). Status Gizi Balita dan Kecemasam Rawan Gizi Kota Yogyakarta Tahun 2010. Yogyakarta: Dinas Kesehatan Kota Yogyakarta.

Elzaky, J. (2011). Mukjizat Kesehatan Ibadah. Jakarta: Penerbit Zaman

Fidianty, I. \& Noviastuti, A. (2010). Kecemasan pada wanita hamil pasca abortus. Artikel. Semarang: Universitas Diponegoro.

Hawari, D. (1997). Ilmu kedokteran jiwa dan kesehatan jiwa. Yogyakarta: PT. Dhana bakti Prima Yasa. 
Kuchan, K. L. (2007). Prayer as therapeutic process toward aliveness within a spiritual direction relationship. Journal of Religion Health. 47, 263-275.

Kushartanti, W., Soekamti, E, R, . \& Sriwhayuniati, C, F. (2004). Senam hamil: menyamarkan kehamilan, mempermudah persalinan. Yogyakarta: Lintang Pustaka.

Kusumajati, R. (2012). Hypnobirthing therapy untuk mengurangi kecemasan menghadapi persalinan pertama. Tesis. (Tidak Diterbitkan). Yogyakarta: Universitas Islam Indonesia.

Lestariningsih, S. (2005). Berpikir positif sejalan. Ayahbunda. Jakarta: PT. Aspirasi Pemuda

Levin, R.I. (2005). Statistic for Management, 7th edition. Englewood Cliffs: Prentice Hall.

Maimunah, A. \& Retnowati, S. (2011). Pengaruh Pelatihan Relaksasi dengan Dzikir untuk Mengatasi Kecemasan Ibu Hamil Pertama. Psikoislamika, Jurnal Psikologi Islami. 8(1), 1-22.

Mandasari, E. (2010). Tingkat Kecemasan Ibu Primigravida dan Multigravida Menjelang Persalinan di Klinik $\mathrm{Hj}$. Hamidah Nasution. Karya Tulis. Surakarta: Stikes Kusuma Husada

Mardiyono \& Songwathana, P. (2009). Islamic Relaxation Outcome: A Literature Review. The Malaysian Journal of Nursing. 1(1), 25-30.
Mulyadi, Hidayah, R \& Mahfur, M. (2012). Model psikoterapi AlQur'an dalam menanggulangi kecemasan santri lembaga tinggi pesantren luhur dan pondok pesantren Baiturrhamah di kota Malang. Jurnal Universitas Islam Negeri Maulana Malik Ibrahim.

Najati, M, U. (2004). Psikologi dalam Perspektif Hadits. Jakarta: Pustaka Al Husna Baru.

Nashori, F. (2005). Hubungan antara kualitas dzikir dengan suasana hati negatif mahasiswa. Penelitian Individu. (Tidak Diterbitkan). Yogyakarta: Universitas Islam Indonesia.

Nolan. 2003. Ilmu Kesehatan Jiwa. Jakarta: Trans Info Media.

Prapto, D. A. P. (2013). Hubungan antara Kualitas dan Integritas Membaca Al-quran dengan Kecemasan Menjelang Kelahiran pada Ibu Hamil Anak Pertama. Skripsi. (Tidak Diterbitkan). Yogyakarta: Universitas Islam indonesia.

Purwoko, S.B. (2013). Terapi Refleksi AlFatihah. Jurnal Psikologika. 18(2), 129-141

Qadri, M. A. (2003). Quranic Therapy Heal Yourself. USA: Islamic Cultural Research Center of North America.

Rahmawati, W.R. (2010). Perbedaan Tingkat Kecemasan lbu Primigravida Trimester III Sebelum dan Sesudah Pemberian Musik Klasik Di Wilayah Kerja Puskesmas 
Magelang Utara. Jurnal Kebidanan. 2(2), 10-20.

Resmaniasih, K. (2014). Pengaruh Teknik Pernafasan Diafragma terhadap Kecemasan pada Ibu Hamil Trimester III. Tesis. (Tidak Diterbitkan). Semarang: Universitas Diponegoro.

Sholeh, A.Y. (2010). Berdzikir untuk Kesehatan Syaraf. Jakarta: Penerbit Zaman

Sijangga, N. W. (2010). Hubungan Strategi Coping dengan Tingkat Kecemasan Ibu Bersalin Hipertensi di RSU Kabupaten Boyolali. Skripsi. (Tidak Diterbitkan). Surakarta: Universitas Muhammadiyah Surakarta.

Sukandar, A. (2009). Keefektifan Cognitive Behavior Therapy (CBT) untuk Menurunkan Tingkat Kecemasan pada Ibu Hamil di Rumah Sakit PKU Muhammadiyah Surakarta. Tesis. (Tidak Diterbitkan). Surakarta: Universitas Sebelas Maret.

Suprijati. (2011). Efektivitas Pemberian Aromaterapi untuk Menurunkan
Kecemasan Ibu Hamil Trimester III dalam Persiapan Menghadapi Persalinan di Bidan Praktek Mandiri Suprijatu Desa Bagi Kecamatan/Kabupaten Madiun. Penelitian Individu. (Tidak Diterbitkan). Ponorogo: Akademi Kebidanan Harapan Mulya.

Susmayanti, H. (2014). Angka Kematian Ibu Melahirkan di DIY Tinggi dari jogja.tribunnews.com/2014/05/28/ angka-kematian-ibu-melahirkan-didiy-tinggi diunduh pada tanggal 24 November 2015.

Trimulyaningsih, N. (2009). Terapi Kognitif Perilakuan Religius untuk Menangani Depresi. Tesis. Yogyakarta: Universitas Gadjah Mada.

Yosep, I. (2007). Keperawatan Jiwa. Bandung: Refika Aditama,

Zamriati, W.A, Hutagaol, E., \& Wowling, F. (2013). Faktor-Faktor yang Berhubungan dengan Kecemasan Ibu Hamil Menjelang Persalinan di Poli KIA PKM Tuminting. Ejournal Keperawatan. Vol. 1(1). 